\title{
Pengembangan Media Game Side Scrolling dalam Meningkatkan Kemampuan Koneksi Matematika
}

\author{
Dyah Putri Handayani ${ }^{*}$, Wahyudi ${ }^{2}$, Endang Indarini ${ }^{3}$ \\ ${ }^{123}$ Pendidikan Guru Sekolah Dasar, Universitas Kristen Satya Wacana Salatiga
}

\begin{abstract}
Abstrak
Keywords:

Penelitian ini bertujuan untuk pengembangan dan pengujian validitas,

Media pembelajaran, Game Side Scrolling, Kemampuan Koneksi kepraktisan, dan keefektifan media game side scrolling pada proses belajar mengajar matematika di sekolah dasar. Metode penelitian yang diterapkan adalah R\&D melalui Matematika desain ASSURE yang terdiri dari enam tahap diantaranya adalah "1) analyze learner (analisis karakteristik siswa); 2) state objectives (menetapkan tujuan proses belajar mengajar); 3) select method, media, and materials (memilih metode, media, dan bahan ajar); 4) utilize media and materials (memanfaatkan media dan bahan ajar); 5) require learner participation (melibatkan siswa dalam kegiatan proses belajar mengajar); dan 6) evaluate and revise (evaluasi dan revisi)". Validitas produk dengan uji pakar melalui instrumen validasi pakar. Kepraktisan produk diuji tes terbatas 10 siswa dengan pemberian angket untuk melihat respon siswa setelah menggunakan media game side scrolling. Keefektifan produk dilakukann dengan tes satu kelas dengan one grup pretest-posttest design yang hasilnya diuji menggunakan Paired Samples T-Test dengan SPSS 22.0. Hasil penelitian adalah media game side scrolling meningkatkan kemampuan koneksi. Media pembelajaran dinyatakan valid berdasarkan uji pakar media, materi, pembelajaran, dan soal. Media pembelajarn dinyatakan praktis berdasarkan hasil anget respon siswa. Media pembelajaran dinyatakan efektif berdasarkan rata-rata hasil pretest dan posttest dan temuan tes Paired Samples T Test pretest-posttest memperlihatkan nilai Sig. (2-tailed) 0,000.
\end{abstract}

\section{PENDAHULUAN}

Seiring perkembangan zaman, tuntutan pendidikan semakin berkembang. Proses belajar mengajar yang diharapkan tidak hanya terpaku pada hafalan, namun lebih menekankan pada kemampuankemampuan siswa yang lainnya. Terdapat lima kemampuan yang harus diperoleh siswa dalam proses belajar mengajar diantaranya adalah pemecahan masalah (probem solving), penalaran dan pembuktian (reason and proof), komunikasi (communication), koneksi (connection), serta representasi (representation) (Yuniawatika, 2011). Dari beberapa kemampuan tersebut, terdapat satu fokus kemampuan yang perlu dikembangkan yaitu kemampuan untuk berelasi atau berkoneksi.

Kemampuan berkoneksi adalah keahlian yang terhubung atau terkait dengan kasus matematika pada lingkungan di sekitar atau mengaitkan matematika pada cabang ilmu lain (Muchlis dkk, 2018). Pada kenyataannya, kemampuan koneksi siswa masih tergolong cukup rendah. Siswa masih belum dapat mengaitkan mata pelajaran matematika terhadap cabang ilmu lain. Hal ini diketahui ketika penulis melakukan observasi langsung di lapangan serta wawancara dengan guru kelas. Dalam rangka meningkatkan kemampuan koneksi, diperlukan adanya suatu alat bantu untuk mempermudah siswa dalam mengembangkan kemampuan koneksi yanag dimilikinya.

Adapun alat bantu yang dimaksudkan berupa media pembelajaran yang dapat mempengaruhi ketertarikan dan semangat siswa dalam mengikuti proses belajar mengajar. Media pembelajaran ialah

* Corresponding author.

E-mail Addresses: - dyahputrihandayani@gmail.com (Dyah Putri Handayani) 
suatu fasilitas yang diterapkan oleh guru memiliki tujuan dalam menyampaikan pesan oleh pengirim dan penerima, selain itu juga dapat mendorong pikiran, perasaan, perhatian dan minat siswa (Alfian I, 2019). Selain menggunakan media, diperlukan juga penerapan metode pembelajaran yang tepat guna mendukung terciptanya proses belajar mengajar yang menyenangkan sehingga siswa dapat lebih tertarik lagi dalam mengikuti pembelajaran di kelas.

Namun pada kenyataannya, proses belajar mengajar masih berkutat pada metode konvensional dimana siswa disuguhi buku ajar dan hanya melakukan kegiatan seperti apa yang ada di dalam buku. Implementasi metode proses belajar mengajar yang kurang bervariasi serta tidak adanya penerapan media pembelajaran yang tepat dapat mengakibatkan proses belajar mengajar terasa monoton dan tidak memiliki kreatifitas (Masykur, Nofrizal, \& Syazali, 2017). Oleh karena itu, penulis melakukan penelitian dengan menerapkan metode dan media pembelajaran yang tepat agar dapat meningkatkan kemampuan koneksi siswa.

Adapun media yang akan dikembangkan adalah media game side scrolling yang diberi nama Bakuta. Side scrolling platformer merupakan salah satu kategori permainan video game dimana game world disajikan dengan tampilan tiga dimensi dan game play yang melibatkan perjalanan antar platform dengan cara meloncat. Kursor maupun navigasi pada keyboard untuk mengarahkan pergerakan game dari arah kanan ke kiri atau sebaliknya. Media ini dapat menciptakan suasana bermain sambil belajar.

Media ini dikembangkan berdasarkan permasalahan yang ditemui oleh peneliti di lapangan, yaitu kurang berkembangnya kemampuan koneksi yang dimiliki oleh siswa. Media ini juga dilengkapi dengan sebuah permasalahan matematis yang kontekstual. Permasalahan yang terdapat dalam game melatih siswa untuk dapat menyelesaikan permasalahan yang ada menggunakan matematika. Jadi, media ini dirancang secara khusus agar dapat meningkatkan kemampuan koneksi matematika siswa.

\section{METODE PENELITIAN}

Penelitian ini ialah jenis penelitian R\&D dengan model pengembangan ASSURE. Model dikembangkan dalam 6 tahap diantaranya adalah 1) analyze learners (menganalisis karakteristik siswa); 2) state objectives (menentukan tujuan); 3) select method, media, and materials (memilih metode, media dan materi); 4) utilize media and materials (memanfaatkan media dan materi); 5) require leraner participation (melibatkan siswa dalam kegiatan pembelajaran)); 6) evaluate and revise (evaluasi dan revisi) (Smaldino, Lowther, \& Russell, 2012). Secara jelas, tahapan ASSURE dapat dilihat pada gambar 1 berikut.

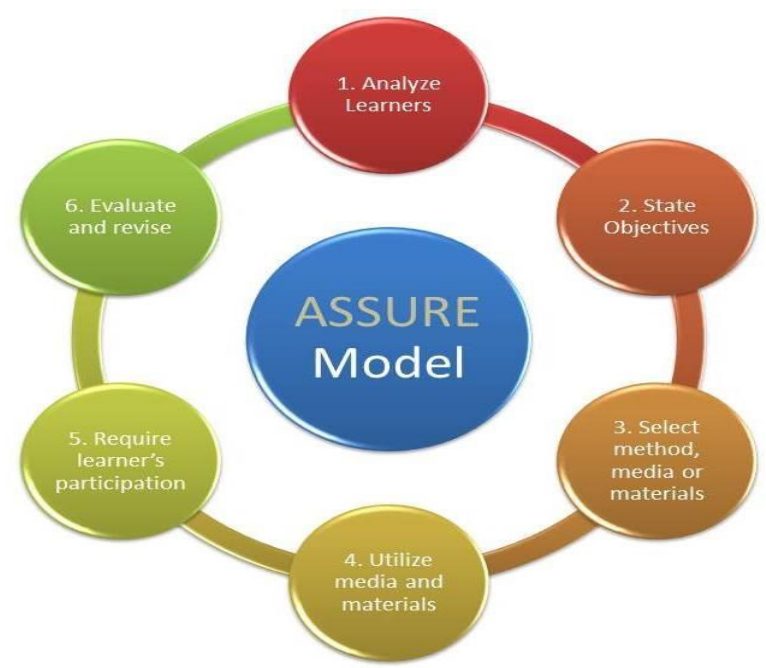

Gambar 1. Model Pengembangan ASSURE berikut ini:

Berdasarkan tahapan-tahapan pengembangan model ASSURE dengan rinci dijelaskan sebagai 1. Analyze learners (Analisis karakteristik siswa)

Tahap pertama yang perlu dilakukan diantaranya yakni menganalisis karakteristik siswa yang terdiri dari kemampuan awal siswa dan cara belajar siswa. Pada pengambilan data, peneliti melakukan wawancara dengan guru kelas dan memberikan angket kepada siswa. Data ini dijadikan sebagai data awal dalam pengembangan media yang sesuai dan efektif. Subjek dalam penelitian ini adalah guru dan siswa kelas V SD Negeri Balesari, Kecamatan Balesari, Kabupaten Temanggung. 


\section{2) State objectives (Menetapkan tujuan proses belajar mengajar)}

Tahap kedua adalah menetapkan tujuan proses belajar mengajar yang didasarkan pada hasil analisis karakteristik siswa. Sebelum menentukan tujuan proses belajar mengajar, peneliti menentukan kompetensi dasar (KD) dan indikator sesuai dengan kurikulum 2013. Tujuan proses belajar mengajar diperoleh dari merumuskan kompetensi dasar (KD) dan indikator yang sudah ditentukan. Pada prinsip ini diharapkan hubungan antara materi proses belajar mengajar memiliki daya tarik dalam menumbuhkan kemampuan koneksi siswa.

3) Select method, media, and materials (Memilih metode, media dan bahan ajar)

Tahap ketiga adalah menetapkan metode, media, dan bahan ajar yang akan diterapkan dalam proses belajar mengajar siswa. Dengan penetapan ketiga komponen tersebut, memegang peranan penting dalam membantu siswa untuk mencapai tujuan proses belajar mengajar yang sudah ditetapkan. Penentuan ketiga komponen tersebut berdasarkan karakteristik siswa serta tujuan proses belajar mengajar menggunakan game side scrolling.

\section{4) Utilize media and materials (Memanfaatkan media dan bahan ajar)}

Tahap keempat pada pengembangan ini adalah menggunakan media serta bahan ajar oleh siswa dan guru. Sebelum diterapkannya media dan bahan ajar tersebut, perlu dilakukannya validasi/uji pakar (pakar media, pakar materi, pakar proses belajar mengajar, dan pakar soal) dalam melihat kualitas serta kelayakan media yang dikembangkan. Setelah melakukan validasi/uji pakar, selanjutnya dilakukan tes terbatas dalam kelompok kecil sebanyak 10 siswa dalam melihat kepraktisan media yang dikembangkan.

5) Require learner participation (Melibatkan siswa dalam kegiatan proses belajar mengajar)

Langkah kelima adalah melibatkan siswa dalam proses belajar mengajar di dalam kelas. siswa mengikuti proses belajar mengajar di dalam kelas sesuai dengan rancangan yang sudah ditetapkan. Proses proses belajar mengajar dilakukan dengan menggunakan game side scrolling dengan harapan dapat meningkatkan kemampuan koneksi siswa serta pemahaman siswa terhadap materi proses belajar mengajar.

6) Evaluate and revise (evaluasi dan revisi)

Tahap keenam ialah tahap terakhir dari pengembangan ini adalah evaluasi dan revisi. Pada kegiatan ini dilakukan agar mendapatkan data dalam mengukur kemampuan siswa serta mendapatkan data kelebihan dan kelemahan media yang dikembangkan. Tahap ini dilakukan melalui pengolahan data pretest dan posttest kemampuan koneksi menggunakan SPSS 22.0 for windows dalam dilakukan uji Paired Samples T Test, serta hasilnya diterapkan dalam memperbaiki media yang dikembangkan.

Teknis Analisis Data

Data hasil validasi produk oleh pakar dianalisis menggunakan teknik deskriptif presentase dan kategoris dalam menggambarkan kelayakan media. Skor hasil pengukuran dengan menggunakan angket tertutup, kemudian skor dipresentasikan dengan menggunakan rumus:

$A P=\frac{\text { Skor Aktual }}{\text { Skor Ideal }} \times 100 \%$

Keterangan

$\mathrm{AP} \quad=$ Angka Presentase

Skor Aktual = Skor yang diberikan

Skor Ideal =Skor maksimal hasil kali antara jumlah item dengan skor maksimal masing-masing item. Angka presentase selanjutnya dikelompokkan menjadi lima kategori sebagai berikut.

Tabel 1. Kategori nilai Persentase

\begin{tabular}{cc}
\hline Interval & Kategori \\
\hline $81-100 \%$ & Sangat tinggi \\
$61-80 \%$ & Tinggi \\
$41-60 \%$ & Cukup \\
$21-40 \%$ & Rendah \\
$1-20 \%$ & Sangat rendah \\
\hline
\end{tabular}

Berdasarkan kategori presentase diatas, maka media game side scrolling dinyatakan layak dalam diujicobakan apabila angka presentase minimal mencapai kategori tinggi ( $\geq 61 \%)$.

Uji kepraktisan dilakukan dengan analisis hasil respon siswa ketika tes terbatas media game side scrolling. Keefektifan di uji dengan melakukan analisis komparatif, yakni membandingkan hasil proses belajar mengajar sebelum dan sesudah penerapan media game side scrolling dalam satu kelas dengan one 
grup design pretest-posttest menggunakan kriteria kemampuan koneksi terdiri dari aspek koneksi dalam matematika, koneksi antar topik matematika, koneksi antar materi matematika dengan ilmu lain, dan koneksi antar matematika dengan kehidupan sehari-hari. Pada hasil dari empat kriteria diterapkan dalam menentukan skor akhir. Skor akhir sebelum dan sesudah penerapan media dibandingkan dengan uji $\mathrm{T}$ sampel berpasangan (Paired Samples T Test) melalui SPSS 22.0 for windows.

\section{ANALISIS DAN PEMBAHASAN}

Pengembangan produk ini dilakukan dengan model ASSURE. Berikut ini enam tahap pengembangan dalam model ASSURE.

Analyze learners (Analisis karakteristik siswa)

Pada tahap ini, penulis menggunakan instrumen angket guna mengetahui karakteristik siswa dilihat dari gaya belajar, kemampuan awal memahami materi bangun ruang, serta kemampuan menggunakan android untuk game side scrolling. Hasil yang diperoleh dapat dilihat pada Tabel 2 dibawah ini.

Tabel 2. Hasil Analyze Learners (Analisis karakteristik siswa) pada Kondisi Awal

\begin{tabular}{lllc}
\hline \multirow{2}{*}{ No } & Kompetensi & Jumlah Siswa dan Persentase \\
& & Sudah & Belum \\
\hline 1 & Siswa memiliki gaya belajar visual & $20(83 \%)$ & $4(17 \%)$ \\
2 & Siswa mengetahui sifat, bentuk dan volume bangun & $18(75 \%)$ & $6(25 \%)$ \\
& ruang (kubus,balok) & $19(79 \%)$ & $5(21 \%)$ \\
3 & Siswa mengetahui game side scrolling & & \\
\hline
\end{tabular}

Mengacu pada temuan pada Tabel 1 didapatkan informasi bahwa 20 siswa dengan persentase sebesar $83 \%$ memiliki gaya belajar visual sedangkan $17 \%$ lainnya memiliki gaya belajar auditori dan kinestetik. Dilihat dari aspek materi, sebanyak 18 siswa dengan persentase $75 \%$ telah mengetahui bagaimana sifat, bentuk maupun cara menghitung volume bangun ruang baik kubus maupun balok. Sebanyak 19 siswa dengan persentase $79 \%$ telah mengetahui apa itu game side scrolling dan bisa memainkannya, sedangkan 5 siswa lainnya dengan persentase 21 belum mengetahu game tersebut.

Selain menggunakan angket, peneliti juga melakukan wawancara terhadap guru kelas guna mengetahui bagaimana cara guru mengajar serta karakteristik siswa selama proses pembelajaran berlangsung. Dari hasil wawancara, dapat diketahui bahwa guru menerapkan pembelajaran dengan metode konvensional dan kegiatan yang dilakukan hanya terpaku pada buku yang digunakan sehingga siswa cenderung bosan selama pembelajaran.

State objectives (Menetapkan tujuan proses belajar mengajar)

Tahap kedua adalah menetapkan tujuan pembelajaran yang didasarkan pada hasil analisis kebutuhan dan karakteristik siswa. Peneliti menentukan kompetensi dasar dan indikator yang sudah ditetapkan pada kurikulum 2013, kemudian dirumuskan menjadi tujuan pembelajaran yang akan dicapai. Sebelum menetapkan tujuan proses belajar mengajar, langkah awal adalah menentukan kompetensi dasar (KD) dan indikator proses belajar mengajar yang dapat dirumuskan pada Tabel 3 sebagai berikut:

Tabel 3. Kompetensi Dasar dan Indikator

\begin{tabular}{|c|c|c|c|}
\hline No & Kompetensi Dasar & No & Indikator \\
\hline \multirow[t]{3}{*}{3.5} & \multirow{3}{*}{$\begin{array}{l}\text { Menjelaskan, dan menentukan volume } \\
\text { bangun ruang dengan menggunakan } \\
\text { satuan volume (seperti kubs satuan) } \\
\text { serta hubungan pangkat tiga dengan akar } \\
\text { pangkat tiga. }\end{array}$} & 3.5 .1 & $\begin{array}{l}\text { Menentukan volume kubus dan balok } \\
\text { dengan menggunakan satuan volume }\end{array}$ \\
\hline & & 3.5 .2 & $\begin{array}{l}\text { Memecahkan masalah volume kubus } \\
\text { dan balok menggunakan satuan volume }\end{array}$ \\
\hline & & 3.5 .3 & $\begin{array}{l}\text { Menyimpulkan unsur dan volume kubus } \\
\text { serta balok menggunakan satuan } \\
\text { volume }\end{array}$ \\
\hline 4.5 & Menyelesaikan masalah yang berkaitan & 4.5.1 & Menyajikan penyelesaian masalah yang \\
\hline
\end{tabular}




\begin{tabular}{ll}
\hline dengan volume bangun ruang & berkaitan dengan volume kubus dan \\
menggunakan satuan volume (seperti & balok menggunakan satuan volume \\
kubus satuan) melibatkan pangkat tiga & \\
dan akar pangkat tiga) &
\end{tabular}

Berdasarkan kompetensi dasar dan indikator, langkah selanjutnya adalah merumuskan tujuan proses belajar mengajar pada saat dilaksanakan proses belajar mengajar. Berikut ialah rumusan tujuan proses belajar mengajar matematika dalam materi spesifik bangun ruang: 1) Dengan disajikan permasalahan terkait dengan volume bangun ruang balok dan kubus melalui game side scrolling, siswa dapat menentukan volume kubus dan balok dengan menggunakan satuan volume dengan benar, 2) Dengan disajikan permasalahan terkait dengan volume bangun ruang balok dan kubus melalui game side scrolling, siswa dapat memecahkan masalah volume kubus dan balok menggunakan satuan volume dengan benar, 3) Dengan disajikan permasalahan terkait dengan volume bangun ruang kubus dan balok melalui game side scrolling, siswa dapat menyimpulkan unsur dan volume kubus serta balok menggunakan satuan volume dengan tepat, dan 4) Dengan melakukan diskusi kelompok menggunakan media pembelajaran game side scrolling, siswa dapat menyajikan penyelesaian masalah yang berkaitan dengan volume kubus dan balok menggunakan satuan volume dengan tepat.

Select Media, Methode, and Materials (Memilih media, metode, dan bahan ajar)

Tahap ketiga adalah memilih metode, media, dan bahan ajar yang akan diterapkan pada saat proses proses belajar mengajar berlangsung. Berdasarkan hasil pada tahap analisis, peneliti memilih untuk menggunakan beberapa variasi metode dan juga media untuk menunjang tercapainya tujuan pembelajaran. Dalam penelitian ini, peneliti mengembangkan media game side scrolling dengan nama Bakuta. Pemilihan penggunaan media game ini berdasarkan hasil analisis yang diperoleh bahwa mayoritas siswa memiliki gaya belajar visual dan juga sudah mengetahui game side scrolling. Dari hasil angket diketahui bahwa siswa senang bermain game side scrolling, jadi peneliti mengembangkan game ini dengan menambahkan materi dalam permainan agar siswa tidak hanya sekedar bermain, namun juga dapat belajar.

Dalam proses belajar mengajar, biasanya guru hanya menggunakan metode ceramah dan juga penugasan. Peneliti masih menggunakan metode yang sama dengan menambahkan variasi metode agar siswa lebih aktif dalam mengikuti pembelajaran. Adapun metode yang dipilih pada saat proses proses belajar mengajar berlangsung diantaranya adalah menggunakan metode ceramah, diskusi, penugasan, dan tanya jawab. Bahan ajar yang dipilih diantaranya adalah buku siswa, buku guru, dan game yang didalamnya telah disediakan permasalahan dalam diselesaikan oleh siswa.

Utilize Media and Materials (Memanfaatkan media dan bahan ajar)

Tahap keempat adalah menggunakan ketiga komponen dalam proses proses belajar mengajar. Komponen yang sudah disusun, kemudian divalidasi/uji pakar yang terdiri dari pakar media, pakar materi, pakar proses belajar mengajar, dan pakar soal. Penilaian pakar ini dilakukan oleh salah satu dosen Pendidikan Matematika di Universitas Kristen Satya Wacana. Hasil uji pakar secara rinci disajikan pada Tabel 4 berikut.

Tabel 4. Hasil Penilaian Pakar

\begin{tabular}{llllll}
\hline No & \multicolumn{1}{c}{ Indikator } & Skor Ideal & Skor Aktual & AP (\%) & Kategori \\
\hline 1 & Media pembelajaran & 75 & 64 & $85 \%$ & Sangat tinggi \\
2 & Materi Proses belajar mengajar & 60 & 52 & $87 \%$ & Sangat tinggi \\
3 & Proses belajar mengajar & 60 & 51 & $85 \%$ & Sangat tinggi \\
4 & Soal Proses belajar mengajar & 50 & 43 & $86 \%$ & Sangat tinggi \\
\hline
\end{tabular}

Berdasarkan kriteria kelayakan media yang dikembangkan terdiri dari media pembelajaran, materi proses belajar mengajar, proses belajar mengajar, dan soal proses belajar mengajar berada dalam kategori sangat tinggi (nilai AP $\geq 61 \%$ ), sehingga media layak diterapkan. 
Tabel 5. Hasil Angket Respon Siswa Tes Terbatas

\begin{tabular}{|c|c|c|}
\hline No. & Pernyataan & Skor \\
\hline 1 & Saya tertarik belajar dengan menggunakan media game Bakuta & 10 \\
\hline 2 & Saya senang dapat belajar dengan menggunakan media game Bakuta & 10 \\
\hline 3 & Saya dapat memahami materi yang ada pada media game Bakuta & 8 \\
\hline 4 & Saya mendapat petunjuk penggunaan media game Bakuta & 9 \\
\hline 5 & $\begin{array}{l}\text { Permasalahan yang ada pada media game Bakuta sering saya temukan di } \\
\text { kehidupan sehari-hari }\end{array}$ & 9 \\
\hline 6 & Saya dapat membaca tulisan yang ada pada media game Bakuta & 10 \\
\hline 7 & $\begin{array}{l}\text { Dengan menggunakan media game Bakuta dapat menambah pengetahuan } \\
\text { saya }\end{array}$ & 8 \\
\hline 8 & Saya dapat memahami bahasa yang ada pada media game Bakuta & 10 \\
\hline 9 & $\begin{array}{l}\text { Saya semakin bersemangat dalam belajar menyelesaikan soal dengan } \\
\text { kemampuan koneksi }\end{array}$ & 8 \\
\hline \multirow[t]{3}{*}{10} & $\begin{array}{l}\text { Setelah bermain, saya terbiasa menyelesaikan soal dengan kemampuan } \\
\text { koneksi }\end{array}$ & 8 \\
\hline & Jumlah & 90 \\
\hline & Presentase & $90 \%$ \\
\hline
\end{tabular}

Berdasarkan hasil angket uji terbatas diperoleh presentase 90\% siswa dapat menggunakan media game side scrolling, sehingga media dapat dikatakan praktis diterapkan.

Sedangkan untuk mengetahui kemampuan koneksi matematika siswa, peneliti menggunakan instrumen pre test dan post test dimana setiap butir soal telah memuat aspek aspek kemampuan koneksi matematika, diantaranya koneksi dalam matematika, koneksi antar topik dalam matematika, koneksi antar materi matematika dengan ilmu lain, dan koneksi antar matematika dengan kehidupan sehari-hari. Hasil data kemampuan koneksi matematika pada saat pretest dan posttest dapat dilihat pada Tabel 6 berikut.

Tabel 6. Penilaian Kemampuan Koneksi Matematika

\begin{tabular}{llccc}
\hline \multicolumn{1}{c}{ Aspek } & Skor & $\begin{array}{c}\text { Pretest } \\
\text { Presentase }\end{array}$ & $\begin{array}{c}\text { Posttest } \\
\text { Skor }\end{array}$ & $\begin{array}{c}\text { Presentase } \\
\text { Koneksi dalam matematika }\end{array}$ \\
Koneksi antar topik dalam matematika & 53 & $74 \%$ & 59 & $82 \%$ \\
Koneksi antar materi matematika dengan ilmu lain & 31 & $42 \%$ & 56 & $78 \%$ \\
Koneksi antar matematika dengan kehidupan sehari-hari & 39 & $53 \%$ & 55 & $76 \%$ \\
\hline
\end{tabular}

Hasil data kemampuan koneksi matematika pada pretest memperlihatkan bahwa ada dua aspek kemampuan koneksi matematika memperoleh presentase kurang dari 50\%, diantaranya adalah ada pada sapek koneksi antartopik matematika sebesar $42 \%$ dan aspek koneksi antar matematika dengan kehiduan sehari-hari sebesar 47\%. Pada data posttest kemampuan koneksi matematika memperlihatkan hasil yang berbeda, dimana semua aspek kemampuan koneksi matematika memperoleh presentase lebih dari 50\%. Hasil posttest memperlihatkan bahwa aspek koneksi dalam matematika memperoleh presentase sebesar 82\%, aspek koneksi antartopik dalam matematika memperoleh presentase sebesar 78\%, aspek koneksi antar materi matematika dengan ilmu lain memperoleh presentase sebesar 76\%, dan koneksi antar matematika dengan kehidupan sehari-hari memperoleh presentase sebesar $81 \%$.

Hasil presentasi kemampuan koneksi matematika secara rinci disajikan pada Table berikut:

Tabel 7. Penilaian Presentasi Kemampuan Koneksi Matematika

\begin{tabular}{|c|c|c|c|}
\hline Kategori & Interval & Frekuensi & Presentase \\
\hline Tinggi & $91-100$ & 8 & $33 \%$ \\
\hline Sedang & $71-90$ & 16 & $64 \%$ \\
\hline Rendah & $61-70$ & - & - \\
\hline \multicolumn{2}{|c|}{ Jumlah } & 24 & $100 \%$ \\
\hline
\end{tabular}


Berdasarkan hasil penilaian presentasi kemampuan koneksi maematika, siswa dengan kemampuan presentasi kategori tinggi sebanyak 8 siswa atau sebesar 33\%, dan yang termasuk dalam kategori sedang sebanyak 16 siswa atau sebesar $64 \%$.

\section{Require learner participation (Melibatkan siswa dalam kegiatan proses belajar mengajar)}

Tahap kelima adalah melibatkan siswa dalam proses belajar mengajar. Siswa harus terlibat aktif dalam proses belajar mengajar dalam dapat dilihat keefektifitasan media yang sudah dikembangkan dalam rangka mencapai tujuan proses belajar mengajar yang sudah ditetapkan. Kegiatan proses belajar mengajar dilakukan sesuai dengan rancangan yang sudah dibuat sebelumnya. Proses belajar mengajar dilakukan pada satu kali pertemuan proses belajar mengajar. Contoh tampilan game side scrolling yang diterapkan dalam proses belajar mengajar.

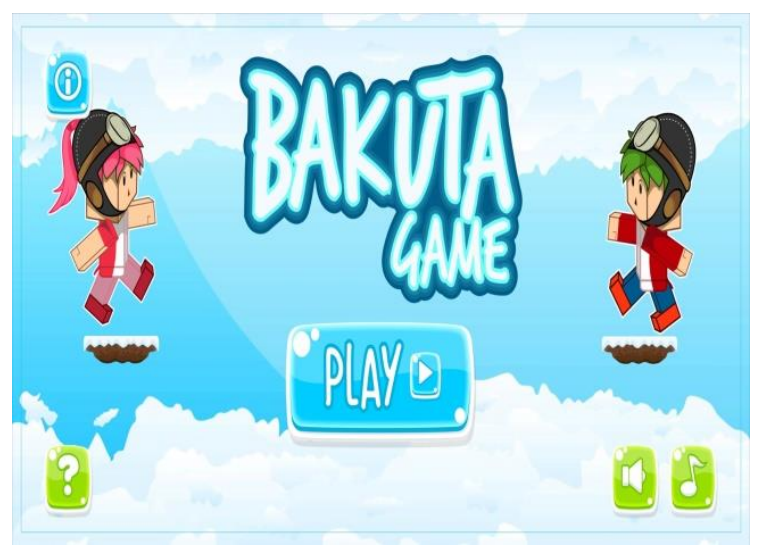

Gambar 2. Tampilan Awal Game

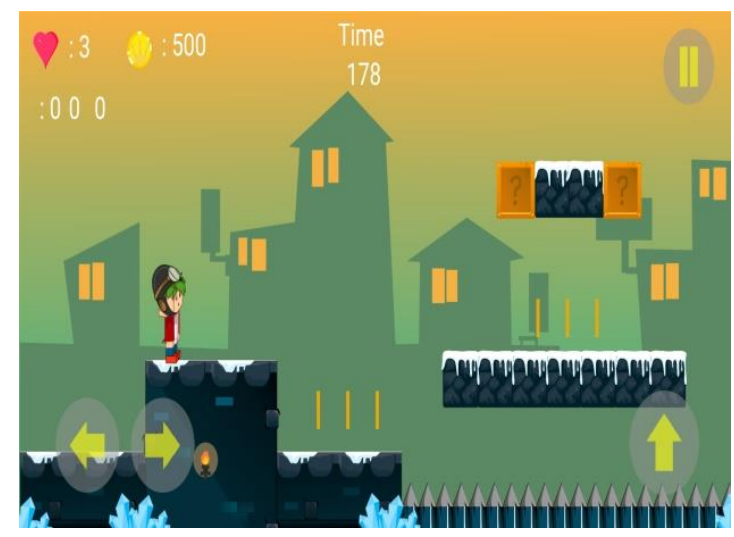

Gambar 3. Tampilan Level 1

Berdasarkan pengolahan data pretest dan posttest menggunakan SPSS 22.0 for windows dalam dilkukan uji Paired Samples T Test. Hasil uji disajikan pada Tabel 8 sebagai berikut.

Tabel 8. Uji T (Paired Samples T Test)

\section{Paired Differences}

95\% Confidence

Interval of the

Std.

Std.

Error Difference

\begin{tabular}{|c|c|c|c|c|c|c|c|c|}
\hline & & Mean & Deviation & Mean & Lower & Upper & $\mathrm{t}$ & tailed) \\
\hline Pair 1 & $\begin{array}{l}\text { Pretest } \\
\text { Posttest }\end{array}$ & $-17,361$ & 5,300 & 1,082 & $-19,599$ & $-15,123$ & $-16,049 \quad 23$ & ,000 \\
\hline
\end{tabular}


Hasil uji memperlihatkan nilai Sig. (2-tailed) sama dengan 0,000 atau kurang dari 0,05, sehingga dapat dikatakan bahwa ada perbedaan yang signifikan sebelum dan sesudah dilakukan proses belajar mengajar menggunakan media game side scrolling. Hasil siswa dengan proses belajar mengajar menggunakan media game side scrolling lebih baik dibandingkan proses belajar mengajar sebelum menggunakan media game side scrolling.

\section{Evaluate and revise (evaluasi dan revisi)}

Tahap keenam yakni melakukan revisi dan evaluasi mengenai media yang dikembangkan. Berdasarkan hasil penilaian pakar serta implementasi proses belajar mengajar ada beberapa kata perintah didalam game side scrolling. Pada bagian pengenalan sifat bangun ruang, jika kalimat itu bukan pengertian ataupun pendapat ahli, maka kata "adalah" diganti dengan menggunakan kata "ialah". Perlu menggunakan Bahasa Indonesia yang baku dan benar. Dengan begitu peneliti melakukan revisi pada bagian kata yang kurang tepat.

Berdasarkan hasil penelitian media game side scrolling dapat meningkatkan kemampuan koneksi matematika. Hal ini dikarenakan siswa mendapatkan proses belajar mengajar dengan menyelesaikan permasalahan menggunakan kemampuan koneksi. Hal ini sejalan dengan aspek kemampuan koneksi matematis yang terdiri dari kegiatan: 1) mengenali representasi ekuivalen dari konsep yang sama, 2) mengenali hubungan prosedur matematika suatu representasi ke prosedur representasi yang lain, 3) menggunakan serta menilai keterkaitan antar topik dan keterkaitan matematika dengan bidang lain, 4) menggunakan matematika dalam kehidupan sehari-hari (Sumarmo, 2010). Selain itu, Anita (2014) menyatakan bahwa keterampilan dalam mengoneksikan sebuah konsep matematika menjadi tahap awal serta syarat utama agar siswa mampu menguasai dan memahami kemampuan lainnya dengan lebih tinggi.

Kemampuan koneksi siswa akan muncul jika siswa diberi kesempatan dalam menguasai serta memahami teori matematika dengan teori matematika maupun ilmu lain dan kehidupan sehari-hari. Kemampuan koneksi yang ada pada siswa sekolah dasar masih tergolong rendah. Hal ini sejalan dengan pendapat Sulistyaningsih (2012) kemampuan koneksi matematika siswa yang rendah dapat mempengaruhi kualitas belajar siswa yang berdampak terhadap rendahnya prestasi siswa di sekolah. Dalam meningkatkan kemampuan koneksi siswa, maka guru harus memperbaiki kualitas belajar siswa. Hal ini sesuai dengan pendapat Siagian (2016) agar siswa berhasil dalam belajar matematika, maka siswa harus diarahkan serta diberi kesempatan penuh dalam melihat keterkaitan atau hubungan antara satu konsep dengan konsep lainnya. Selain itu, keberhasilan belajar siswa dalam meningkatkan kemampuan koneksi akan menciptakan proses belajar mengajar yang bermakna dan menumbuhkan kemauan belajar matematika (Mandur, Sadra, \& Suparta, 2013).

Keberhasilan media game side scrolling dalam meningkatkan kemampuan koneksi matematika juga dipengaruhi oleh materi yang disajikan dalam proses belajar mengajar. Proses belajar mengajar yang menggunakan permasalahan kehidupan sehari-hari, maka siswa secara tidak langsung akan berpikir menggunakan gagasan dalam menghubungkan permasalahan yang disajikan dengan kehidupan seharihari. Seperti yang dikemukakan Hamka (2016), kegiatan berpikir ialah kegiatan menghubung-hubungkan gagasan, membandingan gagasan, mempertentangkan gagasan, memilih gagasan, menafsirkan data, menyimpulkan analisis, serta hal lain dalam memunculkan gagasan aau aspek baru yang akan dituangkan baik dalam tulisan maupun lisan. Semua kemampuan berpikir yang dimiliki oleh masing-masing individu akan menciptakan hal-hal baru, meskipun pada setiap individu memiliki kemampuan yang berbeda. Kemampuan berpikir siswa yang utama ialah menghubung-hubungkan gagasan sehingga setiap individu memiliki kemampuan koneksi yang berbeda.

Kemampuan koneksi dapat dimiliki oleh siswa apabila diberikan kesempatan dalam menganalisis sebuah permasalahan. Maka dari itu, media game side scrolling didesain sesuai dengan karakteristik siswa. Desain game side scrolling yang memuat warna, efek suara, karakter, background, tulisan, dan kegiatan yang terdapat di dalam game disesuaikan agar mampu menarik minat siswa dalam belajar. Materi yang terdapat di dalam game juga disesuaikan dengan materi yang terdapat di kelas V. Di dalam game, siswa diberikan sedikit materi mengenai sifat-sifat bangun ruang, kemudian siswa disajikan sebuah permasalahan yang harus diselesaikan sesuai dengan arahan yang diberikan, serta pada akhir perminan siswa diminta menyusun puzzle dan mengerjakan soal. Selain media, metode yang akan digunakan peneliti adalah ceramah, diskusi, penugasan, dan tanya jawab yang akan diterapkan pada saat pembelajaran di dalam kelas. Peneliti nantinya akan menggunakan bahan ajar buku siswa dan buku guru sebagai acuan. Pemanfaatan media dalam proses belajar mengajar mengakibatkan keinginan serta minat, memberikan semangat dan menimbulkan rasa ingin tahu siswa yang tinggi serta memiliki pengaruh secara psikologi terhadap siswa (Sudirman dalam Alimudin 2015).

Selain itu, keberhasilan dalam penelitian ini didukung dengan adanya peningkatan skor dari pretest ke posttest sehingga ada perbedaan yang signifikan sebelum dan sesudah penggunaan media game side 
scrolling pada kegiatan proses belajar mengajar di kelas. Berdasarkan hasil penelitian dapat dikatakan bahwa media game side scrolling efektif diterapkan dalam proses belajar mengajar. Berdasarkan angket respon siswa setelah menggunakan media game side scrolling, dapat disimpulkan bahwa siswa terbantu dalam memahami materi dan senang mengikuti pembelajaran menggunakan game side scrolling. Hal ini dikarenakan peneliti mengembangkan media game side scrolling yang memberikan aktivitas belajar sambil bermain dengan mengumpulkan koin dan menyelesaikan permsalahan yang sudah tersedia pada setiap level, sehingga setiap individu berlomba-lomba untuk menyelesaikan game terlebih dahulu. Dengan adanya media pembelajaran yang berkaitan dengan aktivitas belajar sambil bermain, siswa tertarik dan menumbuhkan minat untuk mengikuti pembelajaran.

\section{KESIMPULAN}

Berdasarkan hasil penelitian dan pengembangan yang dilakukan, dapat disimpulkan bahwa media game side scrolling dapat meningkatkan kemampuan koneksi matematika dikatakan layak diterapkan dalam proses belajar mengajar. Hal ini ditunjukkan dari dari hasil validasi pakar media, materi, proses belajar mengajar dan soal. Keefektifan media di ditunjukkan adanya perbedan yang signifikan dari hasil pretest dan posttest berdasarkan Paired Samples T Test dengan Sig. (2-tailed) sama dengan 0,000 atau kurang dari 0,05. Kepraktisan media ditunjukkan dari hasil angket respon siswa menggunakan media game side scrolling dalam proses belajar mengajar diperoleh presentase sebesar $94 \%$.

Saran yang diberikan oleh peneliti kepada beberapa pihak dalam dunia pendidikan. Bagi siswa yang suka dengan game diharapkan dapat menambah pengetahuan melalui kegiatan belajar sambil bermain. Saran bagi guru dalam meningkatkan ketertarikan dan semangat belajar siswa agar dapat memilih serta memanfaatkan media pembelajaran yang sesuai dengan karakteristik siswa. Bagi kepala sekolah, supaya mempertimbangkan pemanfaatan media pembelajaran yang sesuai dengan karakteristik siswa serta tuntutan pendidikan pada zaman sekarang. Bagi peneliti selanjutnya, diharapkan dapat menyempurnakan produk dari penelitian ini yang kiranya kurang tepat maupun di kembangkan sesuai dengan tuntutan pendidikan yang akan berlaku di kemudian hari..

\section{DAFTAR PUSTAKA}

Alfian, I. (2019). Pengembangan Media Scrapbook Proses belajar mengajar Tematik Tema 6 Merawat Hewan Dan Tumbuhan Subtema 1 Hewan Di Sekitar Pada Kelas 2 Sekolah Dasar (Doctoral dissertation, University of Muhammadiyah Malang).

Alimudin, A. (2015). Strategi pengembangan minat wirausaha melalui proses proses belajar mengajar. EJurnal Manajemen Kinerja, 1(1), 1-13.

Anita, I. W. (2014). Pengaruh Kecemasan Matematika ( Mathematics Anxiety) Terhadap Kemampuan Koneksi Matematis Siswa SMP. Jurnal Ilmiah Program Studi Metematika STKIP Siliwangi Bandung, 3(1), 125-132.

Hamka, M. (2016). Pengembangan Stategi Pengajaran Bahasa dan Sastra Indonesia Berbasis Budaya dalam Meningkatkan Kearifan Siswa dalam Berkehidupan. Makalah ini disajikan dalam Seminar Nasional Pengembangan Proses belajar mengajar Bahasa dan Sastra Indonesia Berbasis Hasil Penelitian dan Kearifan dalam Berkehidupan, Jurusan Sastra Indonesia, Fakultas Sastra, Universitas Negeri Malang, Malang, 5 November 2016.

Kariadinata, R. (2014). Desain dan pengembangan perangkat lunak (software) proses belajar mengajar matematika berbasis multimedia. Jurnal pendidikan matematika, 1(2).

Mandur, K., Sadra, I. W., \& Suparta, I. N. (2013). Kontribusi Kemampuan Koneksi, Kemampuan Representasi, dan Disposisi Matematis terhadap Prestasi Belajar Matematika Siswa SMA Swasta di Kabupaten Manggarai. e-Journal Program Pascasarjana Universitas Pendidikan Ganesha, 2, 1-10.

Masykur, Nofrizal \& Syazali. (2017). Pengembangan Media pembelajaran Matematika dengan Macromedia Flash. Al-Jabar: Jurnal Pendidikan Matematika, 8(2), 177- 186.

Muchlis, A., Komara, E. S., Kartiwi, W., Nurhayati, N., Hendriana, H., \& Hidayat, W. (2018). Meningkatkan Koneksi Matematis Siswa SMP Melalui Pendekatan Open-Ended Dengan Setting Kooperatif Tipe NHT. KALAMATIKA Jurnal Pendidikan Matematika, 3(1), 81-92. 
Partnership for 21st Century Skills (P21). 2014. Framework for 21st Century Learning. (Online). (http://www.battelleforkids.org/networks/p21, diakses 28 April 2019).

Romli, M. 2016. Profil Koneksi Matematika Siswa Perempuan SMA dengan Kemampuan Matematika Tinggi dalam Menyelesaikan Masalah Matematika. Jurnal Ilmiah Pendidikan Matematika Volum 1 Nomor 2. Hal. 145-157.

Smaldino, S. E., Lowther, D. L., \& Russell, J. D. (2012). Intructional Technology and Media for Learning. New Jersy: Person Merril Prentice Hall Inc.

Sumarmo, U. 2010. Berpikir dan Disposisi matematik: Apa, Mengapa, dan Bagaimana Dikembangkan Pada Siswa. Bandung: UPI.

Sukma, A. P., Nasution, S. P., \& Anggoro, B. S. (2018). Media pembelajaran Matematika Berbasis Edutainment dengan Pendekatan Metaphorical Thinking dengan Swish Max. Desimal: Jurnal Matematika, 1(1), 81-89.

Sulistyaningsih, D. dkk. 2012. Model Proses belajar mengajar Kooperatif Tipe CIRC dengan Pendekatan Konstruktivisme dalam Meningkatkan Kemampuan Koneksi Matematik. Unnes Journal of Mathematics Education Research. Vol. 1. No.2. Halaman: 126.

Siagian, M. D. (2016). Kemampuan Koneksi Matematik dalam Proses belajar mengajar Matematika. MES (Journal of Mathematics Education and Science), 2(1).

Yuliana, N., Pratiwi, D. D., \& Anwar, S. (2019). Pengembangan Media Interaktif Matematika Berbasis Macromedia Flash. Nabla Dewantara: Jurnal Pendidikan Matematika, 3(2), 50-60.

Yuniawatika. (2011). Penerapan Proses belajar mengajar Matematika dengan Strategi React Dalam Meningkatkan Kemampuan Koneksi dan Representasi Matematik Siswa Sekolah Dasar. Edisi Khusus, (1), 105-119. 